\title{
An Exploratory Analysis of the Contexts and Circumstances of Filicide-Suicide in Chicago, 1965-1994
}

\author{
Todd K. Shackelford,* Viviana A. Weekes-Shackelford, and Shanna L. Beasley
}

Florida Atlantic University, Davie, Florida

\begin{abstract}
Filicide is the killing of a ward by a parent. Relative to many other types of homicide, filicide is an infrequent event. Filicide followed by the offender's suicide is less frequent still. The contexts and circumstances surrounding filicide-suicide may nevertheless provide insight into parental psychology. Some research suggests, for example, that filicidal genetic parents are more likely to commit suicide than are filicidal stepparents. Five hypotheses are tested for this study, using a database that includes incident-level information on over 22,000 homicides committed in Chicago during the years 1965-1994. Findings do not support the hypothesis of differential risk of suicide following filicide by genetic parents and stepparents. Previous work is replicated, indicating that: (1) filicides that include multiple victims are more likely to end in the offender's suicide than are filicides that include a single victim, (2) parents are more likely to commit suicide following a filicide of an older child than a filicide of a younger child, (3) older parents, relative to younger parents, are more likely to commit suicide following filicide, and that (4) fathers, relative to mothers, are more likely to commit suicide following filicide. Discussion suggests future directions for research that can inform our understanding of filicide and of filicidesuicide. Aggr. Behav. 31:399-406, 2005. (C) 2005 Wiley-Liss, Inc.
\end{abstract}

Keywords: filicide; filicide-suicide; genetic parents; stepparents; evolutionary psychology

Filicide is the killing of a ward by a parent. Filicide occurs less often than many other types of homicide. Using a national-level Canadian database, for example, Daly and Wilson [1988] reported that of 5,444 solved homicides, the offender in 367 of these cases was a parent of the victim. Within family-related homicides, filicide is still infrequent relative to, for example, uxoricide or wife-killing, but it is more common than familicide, the killing of a spouse and one or more wards. In a national-level Canadian database of 1,324 family-related homicides, for example, 264 were filicides, 1,034 were uxoricides, and just 26 were familicides [Daly and Wilson, 1988]. Although filicide occurs less frequently than some types of family-related

\footnotetext{
*Correspondence to Todd K. Shackelford, Florida Atlantic University, Department of Psychology, 2912 College Avenue, Davie, Florida, 33314. E-mail: tshackel@fau.edu
}

Received 16 June 2003; amended version accepted 10 May 2004

Published online in Wiley InterScience (www.interscience.wiley.com). DOI: 10.1002/ab.20085 
homicides, when it does occur, the emotional and psychological tolls that filicide inflicts on the remaining family members are intense and long-lasting [see, e.g., Daly and Wilson, 1988].

A filicidal parent sometimes commits suicide after killing his or her ward. Although less frequent than filicides not accompanied by suicide, these filicide-suicides are doubly tragic, producing a special grief among the remaining family members [Daly and Wilson, 1988]. Filicide-suicide has not been a topic of focused empirical work. What is known about filicidesuicide indicates, for example, that genetic parents and stepparents may be differently at risk for killing themselves after killing their ward. Using a province-level Canadian database, Cooper and Eaves [1996] reported that 15 of 26 filicides $(57.7 \%)$ perpetrated by a genetic parent were followed by the offending parent's suicide, compared to just one out of nine filicides $(11.1 \%)$ perpetrated by a stepparent. Based on data for 391 Canadian filicides reported by Daly and Wilson [1988], 20\% of filicidal genetic parents committed suicide, compared to just $10 \%$ of filicidal stepparents. Analyzing a national-level Swedish database, Somander and Rammer [1991] reported that 29 of 58 filicides $(50.0 \%)$ perpetrated by a genetic parent ended in the offender's suicide, compared to just one of four filicides $(25.0 \%)$ perpetrated by a stepparent. Finally, in a national-level British database analyzed by Daly and Wilson [1994], 29 of 235 filicidal genetic fathers committed suicide (12.3\%), compared to just two of 131 filicidal stepfathers $(1.5 \%)$.

Filicidal genetic parents apparently are more likely to commit suicide than are filicidal stepparents, and this difference might reflect different psychological processes and motivations operating in genetic parents and in stepparents [see, e.g., Daly and Wilson, 1988, 1998]. There is no clear explanation as yet for this apparent difference in filicide-suicide by genetic parents and by stepparents. If stepparental psychology motivates behaviors such as filicide to dispose of a resource-draining ward to which the person is not genetically related [e.g., Daly and Wilson, 1998), then it would make little adaptive sense for the filicidal stepparent to subsequently kill himself or herself, in which case the stepparent would not reap any benefits associated with eliminating the ward. The current study uses a detailed Chicago homicide database for the years 1965-1994 to test five hypotheses, each of which is designed to replicate and extend previous findings.

Hypothesis 1. Filicidal genetic parents are more likely to commit suicide than are filicidal stepparents.

Some additional previous research has investigated a few other factors that might predict suicide following filicide. These factors include the number of victims killed in the incident, the sex of the offender, the age of the victim (for single-victim incidents), and the age of the offender. Each of these potential predictors of filicide-suicide is addressed in turn. The distinction is made, where possible, between the findings for filicide-suicide by genetic parents and filicide-suicide by stepparents, given the key relevance of genetic relatedness to filicides documented by many researchers, notably Daly and Wilson [see, e.g., 1988; 1998].

Filicidal parents occasionally kill more than one child, in addition to their spouse - a crime known as familicide. Using a Canadian database, for example, Daly and Wilson [1988] found that 26 of 290 filicides $(9.0 \%)$ were familicides. Sometimes the familicidal parent kills himself or herself. In a national-level Canadian database, for example, Wilson et al. [1995] reported that familicidal perpetrators were more likely to commit suicide than were perpetrators of uxoricide and perpetrators of single-victim filicide $(50.9 \%, 25.3 \%$, and $25.3 \%$, respectively). 
We expect to replicate this finding in a larger, city-level database of United States filicides.

Hypothesis 2. Filicides that include multiple victims are more likely to end in the offender's suicide than are filicides that include a single victim.

Although the risk of filicide decreases with the child's age [see, e.g., Daly and Wilson, 1988, 1998], the risk of filicide-suicide increases with the child's age. Parents that kill older children are more likely to commit suicide than are parents that kill younger children [see Daly and Wilson, 1988]. According to parental investment theory [Trivers, 1972], parents value an offspring more as that offspring ages and, therefore, approaches reproductive maturity. Filicide of an older child (who is closer to reproductive maturity) therefore, may be partly attributable to the parent's abnormal psychological functioning, and, accordingly, be more likely to be followed by the offending parent's suicide. The data corroborate this hypothesis. Using a Canadian database, Daly and Wilson [1988], for example, found that 15 of 95 filicidal mothers committed suicide, compared to just two of 88 mothers that killed an infant. Fifty-eight percent of maternal filicide perpetrators were labeled by the investigating officer as mentally incompetent or "insane," but only $35 \%$ of maternal infanticide (the killing of a child less than one year of age) perpetrators received this label. As with mothers, fathers who killed older children killed themselves more often than did fathers who killed infants (44 of 101 versus just four of 38 , respectively). Paternal filicide perpetrators also were more likely to be labeled mentally incompetent or insane $(20.8 \%)$ than were paternal infanticide perpetrators $(15.8 \%)$ ). Parents who kill older children (compared to those that kill younger children) therefore may be more troubled psychiatrically, and suicide following filicide may be a byproduct of this pathology.

Hypothesis 3. Parents will be more likely to commit suicide following a filicide of an older child than following a filicide of a younger child.

Previous research suggests that, not only are the victims of filicide-suicide older than the victims of filicide, but also that the offenders of filicide-suicide are older than the offenders of filicide. Working from an evolutionary perspective, Daly and Wilson [1988] suggested that "normal" older parents tend to value their children more than do "normal" younger parents, because older parents have lower "residual reproductive value" (expected future reproduction) than do younger parents. Filicide by an older parent, therefore, might be more likely to be accompanied by psychiatric problems than filicide by a younger parent. These psychiatric problems, in turn, may include depression and other correlates of suicide. Daly and Wilson [1988] analyzed a Canadian database and presented evidence that corroborated this hypothesis: Infanticidal mothers who committed suicide were significantly older (mean age $=29.5$ years) than infanticidal mothers who did not commit suicide (mean age $=22.5$ years). Similarly, infanticidal fathers who committed suicide were significantly older (mean age $=30.5$ years) than infanticidal fathers who did not commit suicide (mean age $=25.8$ years). We expect to replicate this finding in a larger, city-level database of United States filicides.

Hypothesis 4. Older parents, relative to younger parents, will be more likely to commit suicide following filicide.

There is some evidence that filicidal fathers are more likely to commit suicide than are filicidal mothers. Using a province-level Canadian database, for example, Cooper and Eaves [1996] reported that 13 of 23 paternal filicides (56.5\%) were followed by suicide, whereas only three of 11 maternal filicides $(27.3 \%$ ) were followed by suicide. Analyzing a national-level Swedish homicide database, Somander and Rammer [1991] reported that 24 of 39 filicidal 
fathers $(61.5 \%)$ committed suicide, compared to just six of 23 filicidal mothers $(26.1 \%)$. In a national sample of Canadian homicides, Daly and Wilson [1988] reported that 75 of 177 fathers $(42.4 \%)$ killed themselves following filicide, compared to just 23 of 188 mothers $(12.2 \%)$. This finding will likely be replicated in a larger, city-level database of United States filicides.

Hypothesis 5. Fathers, relative to mothers, will be more likely to commit suicide following filicide.

In summary, a detailed database that includes incident-level information on over 22,000 homicides committed in Chicago from 1965 to 1994 was used, in order to replicate and extend research that identifies several key predictors of filicide-suicide, including the differential likelihood of filicide-suicide among genetic parents and stepparents.

\section{METHODS}

\section{Database and Procedures}

The Chicago Homicide Database provides incident-level information on 22,988 homicides recorded in the murder analysis files of the Chicago Police Department for the years 1965 through 1994 [Block and Block, 1996]. Four hundred fifty-nine cases were selected for analyses in which a child was killed by a stepparent or by a genetic parent. Three hundred ninety-six of these filicides were committed by a genetic parent (209 men, 187 women). Twenty-four filicidal genetic parents (20 men, four women) committed suicide. Sixty-three filicides were committed by a stepparent (60 stepfathers, three stepmothers). Four filicidal stepparents committed suicide, and in each case this was a stepfather.

\section{RESULTS}

According to Hypothesis 1, filicidal genetic parents are more likely to commit suicide than are filicidal stepparents. The results did not support the hypothesis. The percentage of filicidal genetic parents that committed suicide $(6.1 \% ; 24$ of 396) did not differ significantly from the percentage of filicidal stepparents that committed suicide $(6.3 \% ; 4$ of 63$), \chi^{2}(1$, $\mathrm{N}=459)=0.01, \mathrm{p}>.05$. Previous work indicates that a key predictor of child abuse, neglect, and filicide is residence with a stepparent [see, e.g., Daly and Wilson, 1985, 1988, 1998; Wilson and Daly, 1987; Wilson et al., 1980]. For tests of Hypotheses 2 through 5, we first conducted the relevant analysis for all filicides (i.e. collapsing across filicides committed by stepparents and genetic parents). We then conducted parallel analyses separately for genetic parents only and for stepparents only, where possible. Although there were just four cases of stepparental filicide-suicide, we nevertheless conducted the analyses for stepparents only (where possible), to allow for a qualitative comparison with the results of analyses for genetic parents only.

According to Hypothesis 2, filicides that include multiple victims are more likely to end in the offender's suicide than are filicides that include a single victim. The results supported the hypothesis, across all filicides and for filicides committed by genetic parents and by stepparents. Across all filicides, 38\% (19 of 50) of parents that killed multiple victims subsequently killed themselves, whereas just 2.2\% (9 of 409) of parents that killed a single victim subsequently killed themselves, $\chi^{2}(1, \mathrm{~N}=459)=99.68, \mathrm{p}<.05$. For genetic parents, 
a greater percentage of filicides that included multiple victims $(37.2 \% ; 16$ of 43$)$ ended in the offender's suicide, compared to filicides that included a single victim $(2.3 \% ; 8$ of 253$)$, $\chi^{2}(1, \mathrm{~N}=396)=82.21, \mathrm{p}<.05$. For stepparents, a greater percentage of filicides that included multiple victims $(42.9 \% ; 3$ of 7$)$ ended in the offender's suicide, compared to filicides that included a single victim $(1.8 \% ; 1$ of 56$), \chi^{2}(1, \mathrm{~N}=63)=17.65, \mathrm{p}<.05$.

According to Hypothesis 3, parents will be more likely to commit suicide following a filicide of an older child than following a filicide of a younger child. To test this hypothesis, older children are defined as six years or older and younger children as five years or younger. Previous analyses of filicide risk make a similar distinction between older children and younger children [see, e.g., Daly and Wilson, 1988; 1994]. Older filicide victims comprised $28.1 \%$ (129 of 459 ) of filicide cases, and younger filicide victims comprised $71.9 \%$ (330 of 459) of filicide cases. The results supported Hypothesis 3, across all filicides. A greater percentage of filicidal parents of older victims $(12.4 \% ; 16$ of 129$)$ than of younger victims $(3.6 \% ; 12$ of 330$)$ subsequently killed themselves; $\chi^{2}(1, \mathrm{~N}=459)=12.44, \mathrm{p}<.05$. When we conducted the analyses for genetic parents only and for stepparents only, the results supported Hypothesis 3 for genetic parents. A greater percentage of filicidal genetic parents of older victims $(12.9 \% ; 13$ of 101$)$ than of younger victims $(3.7 \% ; 11$ of 295$)$ subsequently killed themselves, $\chi^{2}(1, \mathrm{~N}=396)=11.05, \mathrm{p}<.05$. The same trend was evident for stepparents, but the difference did not reach statistical significance: 10.7\% (3 of 28) of filicidal stepparents of older children subsequently killed themselves, whereas just $2.9 \%$ ( 1 of $35)$ of filicidal stepparents of younger children killed themselves, $\chi^{2}(1, N=63)=1.62$, $\mathrm{p}>.05$.

According to Hypothesis 4, older parents, relative to younger parents, will be more likely to commit suicide following filicide. To test this hypothesis, we first conducted a median split of the data for offender age. "Older" parents are defined as 26 years or older and "younger" parents as 25 years or younger. Older parents comprised 52.1\% (239 of 459) of filicide offenders, and younger parents comprised 47.9\% (220 of 459) of filicide offenders. The results supported Hypothesis 4, across all filicides. A greater percentage of filicidal older parents $(10.5 \% ; 25$ of 239$)$ than filicidal younger parents $(1.4 \% ; 3$ of 220$)$ subsequently killed themselves, $\chi^{2}(1, \mathrm{~N}=459)=16.55, \mathrm{p}<.05$. The results also supported Hypothesis 4 for analyses conducted on genetic parents only. A greater percentage of older filicidal genetic parents $(10.8 \% ; 21$ of 194$)$ than younger filicidal genetic parents $(1.5 \% ; 3$ of 202$)$ subsequently killed themselves, $\chi^{2}(1, \mathrm{~N}=396)=15.16$, $\mathrm{p}<.05$. For stepparents, $8.9 \%$ (4 of 45 ) of older filicidal stepparents subsequently killed themselves. There were no cases in which a younger filicidal stepparent subsequently killed himself or herself; thus, it was not possible to conduct the parallel analysis for stepparents.

According to Hypothesis 5, fathers, relative to mothers, will be more likely to commit suicide following filicide. The results supported Hypothesis 5, across all filicides. A greater percentage of filicidal fathers $(8.9 \% ; 24$ of 269$)$ than filicidal mothers $(2.1 \% ; 4$ of 190$)$ subsequently killed themselves, $\chi^{2}(1, \mathrm{~N}=459)=9.03, \mathrm{p}<.05$. The results also supported Hypothesis 5 for analyses conducted on genetic parents only. For genetic parents, a greater percentage of filicidal fathers $(9.6 \% ; 20$ of 209$)$ than filicidal mothers $(2.1 \% ; 4$ of 187$)$ subsequently killed themselves, $\chi^{2}(1, \mathrm{~N}=396)=9.57, \mathrm{p}<.05$. For stepparents, $6.7 \%$ (4 of $60)$ of filicidal stepfathers subsequently killed themselves. There were no cases in which a filicidal stepmother subsequently killed herself; thus, we could not conduct the parallel analysis for stepparents. 


\section{DISCUSSION}

Using a database that included over 22,000 homicides committed in Chicago for the years 1965 through 1994, the following hypotheses were tested: (1) filicidal genetic parents are more likely to commit suicide than are filicidal stepparents, (2) filicides that include multiple victims are more likely to end in the offender's suicide than are filicides that include a single victim, (3) parents will be more likely to commit suicide following a filicide of an older child than following a filicide of a younger child, (4) older parents, relative to younger parents, will be more likely to commit suicide following filicide, and that (5) fathers, relative to mothers, will be more likely to commit suicide following filicide. Empirical support is presented for four of the five hypotheses, relying primarily on data for genetic parent filicides and filicidesuicides.

Previous research indicates that filicidal genetic parents are more likely to commit suicide than are filicidal stepparents. We did not find support for this hypothesis. An approximately equal percentage of filicidal genetic parents and filicidal stepparents committed suicide $(6.1 \%$ and $6.3 \%$, respectively). The percentage of filicidal stepparents that commit suicide in the current study is reasonably consistent with parallel figures provided by previous research, including research conducted with English, Canadian, and Swedish data [ranging from 1.5\% to $25.0 \%$, averaging $11.9 \%$; Cooper and Eaves, 1996; Daly and Wilson, 1988; 1994; Somander and Rammer, 1991]. The percentage of filicidal genetic parents that commit suicide in the current study is much smaller, however, than observed in previous databases [ranging from $12.0 \%$ to $58.0 \%$, averaging 35.0\%; Cooper and Eaves, 1996; Daly and Wilson, 1988; 1994; Somander and Rammer, 1991].

The failure of the current analysis to replicate previous findings on the differential risk of filicide-suicide by stepparents and genetic parents therefore appears to be attributable to the relatively small percentage of filicidal genetic parents in the current data that commit suicide. There is no clear explanation for this apparent discrepancy with previous work, although it is noted that the current analysis is the first to include data collected on United States filicidesuicides. Filicidal genetic parents residing in the United States may be less likely to commit suicide than filicidal parents residing in other countries and cultures. Future work might first attempt to replicate the current results in another United States homicide database. If the current results are replicated, subsequent research will then need to investigate a cause for what might be a unique feature of filicides committed by genetic parents residing in the United States.

The finding that filicidal parents are more likely to commit suicide following a multiplevictim filicide than following a single-victim filicide is replicated. It is further documented that this is the case for both filicidal stepparents and filicidal genetic parents. There is no clear explanation for why multiple-victim filicides are more likely to be followed by suicide than are single-victim filicides. It is possible that psychiatric illness, notably depression, is more prevalent among perpetrators of multiple-victim filicides than among perpetrators of single victim filicides. One correlate of psychiatric illness - particularly depression - is increased risk of suicide [see Daly and Wilson, 1988]. Future research will need to assess empirically this speculation.

According to Trivers' [1972] parental investment theory, parents value an offspring more as that offspring ages and, therefore, approaches reproductive maturity. Filicide of an older child therefore may be partly attributable to parental psychopathology 
(e.g., depression) and, accordingly, be more likely to be followed by the offending parent's suicide. Analyses in the current study of filicidal genetic parents corroborate this hypothesis. Analyses for stepparents produce a similar pattern of results, although these results do not achieve statistical significance. It is not known whether parents who killed older children in fact suffered from psychiatric problems to a greater extent than did parents who killed younger children. We speculate that this is the case, as has been found in previous work [see, e.g., Daly and Wilson, 1988]. Future analyses of filicides and filicide-suicide would benefit from gaining access to the psychiatric history of the offender to help to clarify this speculation and related speculations about the offender's mental health.

Some previous research indicates that older parents, relative to younger parents, are more likely to commit suicide following filicide [Daly and Wilson, 1988]. This finding was replicated using data on filicides committed by genetic parents, but we could not conduct a parallel analysis for stepparents. No younger filicidal stepparent subsequently committed suicide. Daly and Wilson [1988] argued that "normal" older parents may value their children more than do "normal" younger parents, because older parents have less residual reproductive value than do younger parents. Filicide by an older parent therefore might be more likely to coincide with the parent's psychiatric problems than filicide by a younger parent. These psychiatric problems may include key correlates of suicide, such as depression. Future work will need to empirically address these speculations for the greater likelihood of suicide by filicidal older parents than by filicidal younger parents.

Across several different homicide databases, filicidal fathers are more likely than filicidal mothers to commit suicide [Cooper and Eaves, 1996; Daly and Wilson, 1988; Somander and Rammer, 1991]. This finding is replicated for filicidal genetic parents. Parallel analysis could not be conducted for stepparents, because there were no cases in which a filicidal stepmother subsequently killed herself. One speculation for the greater risk of suicide for filicidal fathers than for filicidal mothers is that this finding is a byproduct of men's greater likelihood of committing suicide. The American Association for Suicidology [2000] reports that, in the United States in 1990, men killed themselves at a rate of 20.4 per 100,000 men. Women, in contrast, killed themselves at a strikingly lower rate of 4.8 per 100,000 women. The fact that filicidal fathers are more likely than filicidal mothers to kill themselves, therefore, may be a byproduct of the fact that men are more likely to commit suicide than are women.

In summary, the current study used a database of nearly 23,000 homicides committed in Chicago during the years 1965 through 1994 to test several hypotheses about the contexts and circumstances of filicide-suicide. Even in this large database, so few filicidal stepparents committed suicide that a comparison of filicide with filicide-suicide committed by genetic parents and by stepparents either is not possible or produces results that must be interpreted with caution and tentativeness. The current study indicates that filicide-suicide may not be an event that is wholly unpredictable, but that instead it may be more likely to occur in certain contexts (e.g., multiple-victim killings) and in certain circumstances (e.g., following paternal filicide). Along with some previous work, the current results begin to shed light on when and why filicide-suicide occurs and, in principle, provide a starting point for determining how to reduce the occurrence of this tragic crime. 


\section{REFERENCES}

American Association of Suicidology. 2000. U.S.A. Suicide. Washington, DC: Author.

versus genetic fathers. Ethol Sociobiol 15: 207-217.

Block CR, Block RL. 1996. Homicides in Chicago, 1965-1994 [Computer file]. $3^{\text {rd }}$ ICPSR version. Chicago, IL: Illinois Criminal Justice Information Authority [producer]. Ann Arbor, MI: Inter-university Consortium for Political and Social Research [distributor].

Cooper M, Eaves D. 1996. Suicide following homicide in the family. Violence Vict 11:99-112.

Daly M, Wilson MI. 1985. Child abuse and other risks of not living with both parents. Ethol Sociobiol 6:197-210.

Daly M, Wilson M. 1988. Homicide. Hawthorne, NY: Aldine de Gruyter.

Daly M, Wilson M. 1998. The truth about Cinderella. London: Weidenfeld \& Nicolson.

Daly M, Wilson MI. 1994. Some differential attributes of lethal assaults on small children by stepfather

Somander LKH, Rammer LM. 1991. Intra- and extrafamilial child homicide in Sweden 1971-1980. Child Abuse Negl 15:45-55.

Trivers RL. 1972. Parental investment and sexual selection. In: Campbell B, editor. Sexual selection and the descent of man; 1871-1971. Chicago: Aldine. (pp. 136-179).

Wilson MI, Daly M. 1987. Risk of maltreatment of children living with stepparents. In: Gelles RJ, Lancaster JB, editors. Child abuse and neglect Hawthorne, NY: Aldine de Gruyter. (pp. 215-232).

Wilson MI, Daly M, Daniele A. 1995. Familicide: The killing of spouse and children. Aggress Behav 21:275-291.

Wilson MI, Daly M, Weghorst SJ. 1980. Household composition and the risk of child abuse and neglect. J Biosoc Sci 12:333-340. 